УДК 347.73

DOI https: / / doi.org/10.32837 / yuv.v0i3.938

\author{
П. Латковський, \\ кандидат юридичних наук, \\ доцент кафедри конституційного, адміністративного та фінансового права \\ Чернівецького юридичного інституту \\ Національного університету «Одеська юридична академія»
}

\title{
ПРИНЦИП ТРАНСПАРЕНТНОСТІ БЮДЖЕТУ ЯК ВАЖЛИВА СКЛАДОВА БЕЗПЕКИ ДЕРЖАВИ
}

Транспарентність (інформаційна відкритість) суспільства $є$ сучасною ознакою діяльності усіх гілок влади, визначає рівень цивілізованості й демократизму відносин між владою і громадянським суспільством, що відповідає проголошеній в Конституції України ідеї побудови правової держави.

Проблема прозорості дій влади на будь-якому рівні сьогодні $є$ особливо актуальною, оскільки прозорість - основна умова відкритості рішень владних структур, становлення демократії. Тенденції відкритості і прозорості державного управління характерні для різних країн, як для країн з усталеною демократією, і для тих, де порівняно недавно почалися демократичні перетворення. Особливого значення набуває розвиток процесів транспарентності в бюджетній діяльності, оскільки бюджет є головним політичним та фінансовим інструментом реалізації соціально-економічної політики, тож дослідження прозорості бюджетного процесу та бюджету є безумовно актуальними. Адже чим прозорішою буде така діяльність, тим більше посилюватиметься довіра до ї̈ проведення. Саме завдяки розширенню інформаційного простору й засобів комунікації у осіб з'являється можливість оцінювати спроможність органів державної влади, захищати інтереси громадян в умовах інформаційної демократії. Да і суспільні вигоди відкритості очевидні. Вона посилює підзвітність посадових осіб та створює політичні ризики для тих урядовців, які працюють нее- фективно або здійснюють нераціональну політику. Відкритість сприяє зростанню довіри, що, у свою чергу, забезпечує ширшу підтримку уряду. I навпаки, не відкритість, непрозорість знижує ефективність діяльності державних установ та виступає чинником деморалізації й дестабілізації суспільства.

Надзвичайно високі темпи соціальних, економічних і культурних змін та висока динамічність сучасних суспільств викликають необхідність адаптації до нововведень, які відбуваються сьогодні, а вони стосуються як окремих громадян, організацій, так і держави в цілому.

Зрозуміло, що лідирують ті країни, які змогли перейти на шлях інноваційного розвитку і створити інноваційну економіку і соціальне середовище, що сприяє інноваціям. Саме в зв'язку 3 цим у світовій практиці протягом останніх десятиліть 3 наростанням затверджується діяльність, спрямована на підтримку і використання інновацій. Цілком природно, що в епіцентрі і наукової, і політичної уваги опиняються, перш за все, ті види інноваційної діяльності, які дають швидкий та значний економічний ефект.

Разом із тим, і в світовій, і у вітчизняній науковій та інноваційній практиці увага сконцентрована на розгляді не тільки технічних, інформаційних, біологічних, а й соціально-гуманітарних технологій. До них слід віднести i ту частину, яка відноситься до сфери політичної влади і управління. 


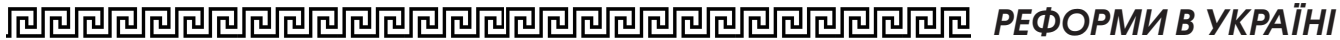

На теперішній час транспарентність (відкритість) публічної влади в будь-якій демократичній країні являє собою не тільки політичне або соціальне явище, a й конституційно-правовий феномен. Транспарентність не зводиться тільки лише до інформованості громадян про діяльність держави і місцевого самоврядування або до реалізації конституційного права на інформацію про діяльність державних або муніципальних органів. Ії можна розглядати як організаційно-правову гарантію народовладдя, як основу конституційного ладу сучасної демократичної держави, як конституційно-правовий принцип організації і діяльності органів публічної влади, а також як соціальне благо, користування яким необхідно кожному в сучасній демократичній державі. А сьогодні особливо важливими постають питання забезпечення належного рівня соціальних стандартів та добробуту кожної української родини. Однак і сформувати бюджет розвитку в теперішніх умовах $€$ непростим завданням, да i проблема забезпечення національної безпеки держави у фінансовій сфері є дуже гострою та важливою для сучасної України. А, як відомо, важливою складовою безпеки держави виступає іi фінансова безпека, яка включає бюджетну, податкову, боргову складові.

Побудова соціально-правової держави залишається пріоритетним напрямом розвитку української держави та одним із найважливіших стратегічних завдань бюджетно-правової політики.

Створення відповідних умов, що забезпечують гідне життя i вільний розвиток людини і громадянина, реалізація їх прав та свобод, в першу чергу - соціальних, в умовах ринкової економіки багато в чому залежать від соціальної орієнтованості діяльності публічно-правових утворень та їх органів в різних сферах, в тому числі в сфері публічних фінансів. Головними завданнями залишаються підвищення добробуту населення i забезпечення стійкого зростання економіки країни на основі стабільного функціонування і розвитку бюджетної системи.

Для втілення в життя різноманітних напрямків соціального розвитку, виконання державою відповідних зобов'язань потрібні значні фінансові ресурси, формування яких може збільшити фіскальне навантаження на бізнес. Необхідно проводити зважену і послідовну бюджетно-правову політику, без якої неможливе забезпечення соціальної стабільності і подолання можливої соціальної напруженості.

Соціальна орієнтованість такої політики багато в чому обумовлена соціальним призначенням самої держави, покликаної діяти в інтересах всього суспільства, 3 метою побудови соціальної держави, політика якої, в тому числі бюджетно-правова, відповідно до Конституції України повинна сприяти створенню умов, що забезпечують гідне життя і вільний розвиток людини та громадянина.

В розроблених Основних напрямів бюджетної політики на 20182020 роки, які грунтуються на положеннях Програми діяльності Кабінету Міністрів України, Коаліційної угоди, Середньострокового плану пріоритетних дій Уряду до 2020 року, Стратегії сталого розвитку «Україна-2020», програм співпраці з міжнародними фінансовими організаціями, зазначено, що основними принципами такої політики мають стати:

прискорення економічного зростання шляхом створення сприятливого інвестиційного клімату та утримання макроекономічної стабільності, зокрема продовження фіскальної консолідаціі;

впровадження ефективного врядування шляхом реформи державного управління, децентралізації і реформи державних фінансів;

розвиток людського капіталу шляхом проведення реформ системи охорони здоров'я та освіти, поліпшення надання державної соціальної підтримки; 


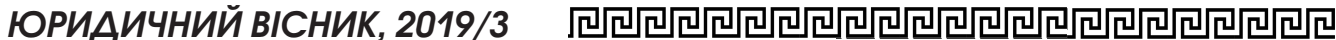

встановлення верховенства права і боротьба 3 корупцією шляхом підтримки ефективного функціонування інститутів боротьби 3 корупцією, забезпечення рівного доступу до правосуддя та ефективного захисту прав власності;

забезпечення безпеки та оборони держави, зокрема захист ї суверенітету та територіальної цілісності держави, а також забезпечення найважливіших аспектів безпеки громадян.

Ці принципи повинні реалізовуватися завдяки створення справедливої системи соціального захисту через проведення пенсійної реформи, осучаснення пенсій, збільшення відповідальності та підзвітності в системі пільг 3 метою забезпечення максимальної адресності, прозорості та наближеності надання відповідної соціальної послуги тим, хто їі потребує; забезпечення гідної оплати праці як для працівників бюджетної сфери, так і для працівників приватного сектору, шляхом їі поступового підвищення та вжиття заходів до детінізації заробітних плат.

Однак багато зауважень є відносно внесених напрямів бюджетної політики на наступні роки. Так, головне науково-експертне управління внесло зауваження щодо Постанови про Основні напрями бюджетної політики на 20182020, відмічаючи, що бюджетна резолюція - це документ, який визначає пріоритети саме бюджетної політики на певний визначений наступний період i $€$ інструментом окреслення реальних фінансових можливостей держави із прив'язкою до державних потреб та планів Уряду, водночас поданий проект Основних напрямів бюджетної політики на 2018-2020 роки є дещо перевантаженим описовими, декларативними та організаційними положеннями, без прив'язки до бюджетної політики та бюджетних пріоритетів держави. Не в повній мірі врахований і правовий вектор соціального спрямування бюджетно-правової політики.

Адже в умовах розвитку демократичної держави бюджетній політиці нале- жить особливе значення, оскільки від якості бюджету, від закладених у ньому параметрів залежить рівень соціальної захищеності громадян, наскільки країна здатна визначити спрямованість та зміст своєї політики, яка повинна сприяти вирішенню як бюджетних питань, так i проблем, пов'язаних з перспективою розвитку даної країни. Перехід української держави до адекватного сприйняття загальновизнаних цінностей сучасної цивілізаціі, формування дійсно демократичної правової системи, правової країни суттєво активізують і вивчення проблем фінансової діяльності країни.

Адміністративна реформа торкнулася практично всіх сфер функціонування державних органів. Один 3 основних напрямків іi проведення $€$ фінансово-контрольна діяльність держави. Мета реформи - створення системи управління публічними фінансами, спрямованої на забезпечення сталого економічного зростання й гарантованого виконання державою своїх соціальних зобов'язань за рахунок: оптимізації управління публічними фінансами, посилення фіскальної дисципліни та проведенням контролю за прозорістю публічних фінансів, транспарентністю бюджету, за дотриманням бюджетного законодавства.

Міжнародний стандарт вимог до транспарентності був прийнятий Радою керуючих Міжнародного валютного фонду (МВФ) у 1998 р. у формі «Кодексу (декларації принципів) щодо забезпечення прозорості в бюджетно-податковій сфері»[1]. Кодекс рекомендовано для застосування, зокрема, в країнах із перехідною економікою, де питання транспарентності є особливо гострими. Необхідність цього документа обумовлена тим значенням, яке має належне державне управління для забезпечення економічного зростання і суспільної стабільності. Ключовою умовою такого управління $€$ забезпечення відкритості та прозорості в бюджетній сфері. Згідно зі згаданим Кодексом транспарентність бюджетної 


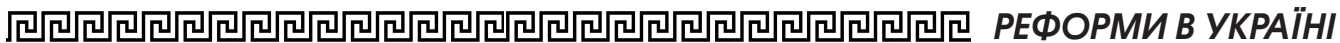

сфери має відповідати чотирьом основоположним принципам.

Принцип визначеності ролі і функцій вимагає чіткого розмежування діяльності органів державного управління між бюджетною, грошово-кредитною сферою, державними підприємствами, державним і приватним секторами в цілому.

Принцип доступності інформаціï передбачає як наявність повної бюджетної інформації, так і їі обов'язкову публікацію у визначені строки. При цьому поняття повноти інформації виходить за межі публікації показників державного чи місцевого бюджету в газетах. Ідеться про більш розширені і детальні матеріали.

Принцип відкритості підготовки i виконання бюджету та бюджетної звітності стосується питань достовірності інформації, іiі відповідності установленим нормам, міжнародним статистичним і бухгалтерським стандартам.

Принцип незалежних гарантій достовірності забезпечує такі гарантії за допомогою зовнішнього аудиту та незалежних перевірок.

Для країн із перехідною економікою мінімальний стандарт транспарентності в бюджетній сфері зводиться до певних основоположних вимог, що передбачають суспільну доступність фінансової інформації своєчасно і в повному обсязі, серед яких:

визначення і діяльність органів державного управління мають відповідати вимогам системи національних рахунків або вказівкам МВФ щодо статистики державних фінансів;

органи державного управління мають розглядати позабюджетну діяльність у рамках бюджетного процесу;

необхідно запровадити законодавчу й адміністративну основу бюджету, що охоплює як бюджетну, так і позабюджетну діяльність із конкретизацією функцій управління бюджетною сферою;

правила оподаткування мають визначатися силою закону, на адміністративне застосування податкового права повинні поширюватися процедурні гарантіі;

позабюджетна діяльність має бути відображена в бюджетній документації та матеріалах обліку;

у бюджетну документацію належить включати початкові й уточнені бюджетні розрахунки за попередні два роки.

Сьогодні на практиці вимоги транспарентності бюджету зосереджуються не на його формуванні та законодавчих основах бюджетної діяльності, а на вимогу більш детального представлення громадськості даних про витрачання коштів. Адже зараз вимоги про транспарентність бюджетної діяльності, наприклад, ніяк не закріплені в чинному законодавстві. Тож, для підвищення рівня відкритості та прозорості бюджетного процесу могло б сприяти законодавче закріплення у Бюджетному кодексі визначення поняття транспарентності як обов'язку органів державної влади щодо своєчасного надання достовірної і в повному обсязі бюджетної інформації громадськості та засобам масової інформації.

Прозорість бюджетних відносин полягає в:

1) інформуванні населення про всі бюджетні показники на всіх етапах процесу,

2) забезпеченні дохідливості інформування, щоб воно не було формальним,

3) безпосередньої участі населення у формуванні бюджету,

4) контролі за виконанням бюджету з боку громадськості, населення.

Мовою правильного функціонування механізму транспарентності виступає дотримання третіми особами вимог до умов трансляції та якісним характеристикам інформації, а саме: інформація повинна бути зрозумілою, своєчасною, достовірною та достатньою.

Громадяни і бізнес повинні знати, куди спрямовуються сплачені ними податки, що, у свою чергу, вимагає високого рівня прозорості бюджету та бюджетного процесу. 


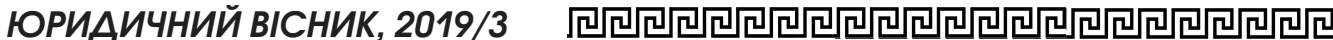

Прозорі системи публічних фінансів - $з$ ефективним наглядом і можливостями громадської участі - вкрай важливі для ефективного використання державних ресурсів в умовах ї обмеженості. Органи виконавчої влади повинні відповідати за прозорість залучення і використання державних коштів, і громадяни мають право брати участь в процесі прийняття рішень в зв'язку з бюджетами, а також у моніторингу того, як виконуються ці рішення.

Громадська участь в процесі формування бюджету сприяє прийняттю рішень і виключно є важливою для відповідальності в бюджетній сфері. Проте, громадська участь не може замінити перевірок з боку законодавчих органів і вищого органу фінансового контролю, які мають повноваження по формальному нагляду за урядами.

Огляд відкритості бюджету оцінює вільний потік бюджетної інформації, практики нагляду з боку законодавчих органів і аудиторів, можливість громадської участі в прийнятті державних рішень i нагляд в бюджетній сфері. Адже прозорий бюджет - це, як правило, основа здорової бюджетної політики, яка дозволяє скоротити дефіцит бюджету і накопичення заборгованості, а також сприяє більшій ефективності економіки.

Інституційні та юридичні аспекти будь-якої країни значно впливають на прозорість і підзвітність в бюджетній сфері та участь громадськості в бюджетному процесі. Дослідження відкритості бюджету серед інших параметрів оцінює ці аспекти, відображаються в ряді питань, пов'язаних із зовнішнім аудитом та парламентським контролем, наприклад, 3 наявністю законодавства про права громадськості на доступ до інформаціі.

Якщо розглядати прозорість бюджету та правові основи громадської участі, то принцип гласності та відкритості означає: офіційне опублікування, оприлюднення (опублікування) іншими способами в встановленому законо- давчими актами порядку нормативно-правових актів про бюджет.

Інтерес в забезпеченні прозорості можуть мати як представники законодавчої (представницької) i виконавчої влади, так і населення і, головним чином, соціально активна частина громадян, яка і представляє інтереси в бюджетному процесі певних груп населення. Хоча інтереси, а отже, і цілі, можуть бути різноспрямованими (виборний процес, підвищення інвестиційної привабливості, контроль за витрачанням бюджетних коштів, отримання коштів з бюджету і т.д.), але загальний вектор підвищення прозорості сприяє реалізації цих цілей.

Суть прозорості бюджету і бюджетного процесу визначається не тільки доступністю інформації для громадськості. Прозорість є необхідною умовою громадської участі, але не достатньою. Прозорість бюджету, будучи інструментом розвитку демократіі, в свою чергу залежить від їі зрілості, тобто готовності і спроможності населення та інститутів громадянського суспільства здійснювати громадський контроль за прозорістю бюджетного процесу і брати участь в ухваленні рішень $з$ питань бюджетної політики, відстоюючи інтереси територіальної громади.

Проблема реалізації принципу прозорості (відкритості) набула нового звучання після проголошення права на інформацію в міжнародних правових актах. У 1948 г. Генеральною Асамблеєю Організації Об'єднаних Націй в ст. 19 Загальної Декларації прав людини було встановлено, що кожна людина має право на свободу переконань і на вільне їх вираження; це право включає свободу безперешкодно дотримуватися своїх переконань і свободу шукати, отримувати i поширювати інформацію та ідеї будь-якими засобами і незалежно від державних кордонів [2].

Дана міжнародно-правова норма стала основою для встановлення права на інформацію і віднайшла подальше 


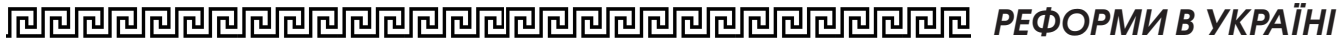

втілення в конституціях багатьох країн, прийнятих після набрання чинності Загальної декларації. Зацікавленість до проблеми підвищення прозорості бюджету в значній мірі підтримується основними міжнародними фінансовими організаціями, серед яких Міжнародний валютний фонд, Світовий банк.

Розглядаючи принцип транспарентності, слід відмітити, що даний принцип в повній мірі не реалізується в практиці бюджетної діяльності. Закон про бюджет на плановий рік постійно ускладнюється, і розібратися пересічному громадянину у відповідних статтях доходів i витрат бюджету дуже складно. 3 метою реалізації принципу прозорості (відкритості) бюджету велике значення має процедура подання звітів про виконання бюджетів всіх рівнів бюджетної системи.

Таким чином, незважаючи на те що бюджетний розвиток йде стрімкими темпами, проблемними залишаються окремі питання, пов'язані 3 транспарентністю бюджету. Внаслідок цього необхідним є поєднання як правових, так і економічних інструментів та методів.

На сьогоднішній день органам державної влади необхідно забезпечити максимальну ступінь відкритості всіх процесів, що відбуваються в сфері державного управління i, зокрема, у фінансовій сфері. Особливо пильна увага в умовах реформування економіки, 3 метою прагнення подолати наслідки світової фінансової кризи та корупції, повинна приділятися процесу використання і витрачання бюджетних коштів.

У статті досліджено транспарентність бюджету як важливої складової безпеки держави. Встановлено, шо особливого значення набуває розвиток проиесів транспарентності в бюджетній діяльності, оскільки бюджет є головним політичним та фінансовим інструментом реалізації соціально-економічної політики держави. Аргументовано, щзо проблема прозорості дій влади на будь-якому рівні сьогодні є особливо актуальною, оскільки прозорість - основна умова відкритості рішень владних структур та становлення демократії. Зазначено, шо побудова соиіально-правової держави залишається пріоритетним напрямом розвитку української держави ma одним із найважливіших стратегічних завдань бюджетно-правової політики. Розкрито основні принципи бюджетної політики держави, яка є невід'ємною складовою фінансової політики. Виокремлено підходи до визначення фінансової ma бюджетної політики та обтрунтовано особливості бюджетної політики. Зроблено висновок про необхідність законодавчого закріплення бюджетної політики на рівні закону ma необхідність забезпечити максимальну ступінь відкритості всіх прочесів, що відбуваються в сфері державного управління $i$, зокрема, у фінансовій сфері. Особливо пильна увага в умовах реформування економіки, з метою прагнення подолати наслідки світової фінансової кризи та корупції, повинна приділятися прочесу використання $i$ витрачання бюджетних коштів. Умови сучасного світу змушують уряди різних країн прагнути до забезпечення принщипу вільного доступу громадськості до публічної інформації. Тож створення найбільш зручних, менш витратних механізмів реалізації даного права громадян є пріоритетом для більшості розвинутих країн.

Ключові слова: бюджет, публічні фінанси, бюджетна політика, фінансова політика, транспарентність, прозорість, відкритість, доступність.

\section{Latkovskyi P. THE PRINCIPLE OF BUDGET TRANSPARENCY AS AN ESSENTIAL COMPONENT OF THE NATIONAL SECURITY \\ The article examines the} transparency of the budget as an important component of state security. It is established that the development 


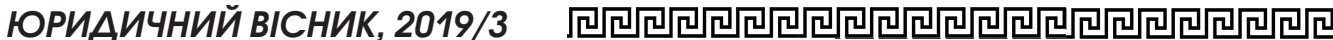

of transparency processes in budgetary activity is of particular importance, since the budget is the main political and financial instrument for the implementation of the socio-economic policy of the state. It is argued that the problem of transparency of actions of the authorities at any level is especially relevant today, since transparency is a basic condition for openness of decisions of governmental structures and the establishment of democracy. It is noted that the construction of a social-legal state remains a priority direction for the development of the Ukrainian state and one of the most important strategic tasks of the budgetary-legal policy. The basic principles of the budgetary policy of the state, which is an integral part of the financial policy, are revealed. The approaches to the definition of financial and budgetary policy are distinguished and the peculiarities of budgetary policy are substantiated. The conclusion is made about the necessity of legislative consolidation of budgetary policy at the level of the law and the need to ensure the maximum degree of openness of all processes that take place in the sphere of public administration and, in particular, in the financial sphere. Particular attention should be paid to the process of using and spending budget funds in the context of economic reform in order to overcome the effects of the global financial crisis and corruption. The conditions of the modern world are forcing governments of different countries to strive for the principle of free public access to public information. Therefore, creating the most convenient, less costly mechanisms for exercising this right of citizens is a priority for most developed countries.

Key words: budget, public finances, budgetary policy, financial policy, transparency, clearness, openness, accessibility.

\section{Література}

1. Кодекс належної практики по забезпеченню прозорості у грошово-кредитній та фінансовій політиці: Декларація принц̧ипів. Документ № 995-950. https: // zakon.rada.gov.ua/laws/show/995_950.

2. Всеобщая декларащия прав человека. Принята резолющией 217 А (III) Генеральной Ассамблеи ООН от 10 декабря 1948 года. https://wrw.un.org/ru/ documents /decl_conv/declarations / declhr. shtml 